\title{
The Influence of Human Capital on Performance and Satisfaction of Medium Entrepreneurs in Kupang City
}

\author{
Syarifuddin ${ }^{1}$, Mahfudnurnajamuddin ${ }^{2}$, Ratna Dewi ${ }^{3}$ \\ ${ }^{123}$ Universitas Muslim Indonesia, Makassar, Indonesia \\ Isyarifuddin.umk@gmail.com \\ ${ }^{2}$ mahfud.nurnajamuddin@umi.ac.id \\ ${ }^{3}$ ratna1001159@gmail.com
}

\begin{abstract}
This aims of this study is to know the influence of human capital on performance and customer satisfaction as well as medium entrepreneur human capital towards the entrepreneurs satisfaction through the performance medium entrepreneurs. This study was conducted in Kupang city with number of population 280 people as medium entrepreneurs. Sample assignment as much as 165 people medium entrepreneurs as respondents by using the method of withdrawal of samples through a formula approach Yamane. Results of the questionnaire on data analysis using Structural Equation Modeling (SEM) programmed package with the helping of Moment Analysis of Structure (AMOS) 18. The study found that; 1) Humana capital positive and significant effect on performance, medium-2) entrepreneur Human capital effect positive use and significantly to the satisfaction of the medium entrepreneurs, 3) positive use of influential businessmen and Performance significantly to satisfaction medium, 4) entrepreneur Human capital effect positive and significantly to the satisfaction of the employers through the performance medium entrepreneurs.
\end{abstract}

Keywords : human capital; performance; satisfaction of entrepreneurs

\section{Introduction}

Through the Ministry of cooperatives and the Small Medium Enterprises of national economic development policy put the Micro small and medium enterprises (UMKM), as a pillar of the national economy is an important factor in encouraging the progress of the national economy are more healthy, independent and competitive.

The growth of economic in Kupang City was supported by trading and services sector, many of the businessmen in Kupang city that move and build his business sector of Small Medium Enterprises especially in medium businesses sector. However, many of the intermediate trade has bad experienced in developing his business. Many factors of intermediate business sectors found problem because of low levels of understanding and ability of employers in the planning, organizing, managing, controlling and supervising the business properly. Understanding weakness management especially in human resource management aspect as an important element which are exploited or used to realize the purpose of the business becomes a factor causes the number of employers who fail to develop his business. According to Furtwangler (2010:85) that human resources management is essential to building an organization or company in order to advance and develop.

Another factor that became the weaknesses found today are many entrepreneurs in the middle business sectors in Kupang city, in managing his business does not pay attention to or consider the application of human capital as a solutions to improve the performance of enterprises and job satisfaction the realization of an entrepreneur in this endeavor. Rudolf (2009:57) stated that the approach to human resource management is solution of improving performance and attainment of job satisfaction. Therefore, a consideration to take notice of the importance of human capital in the middle in order to materialize efforts to manage the achievement of performance and job satisfaction of employers. 


\section{Review of Related Literature}

\subsection{The concept of Human Capital}

Becker (2009:36) look at that man is a form of or is usually called capital which has many forms that can be harnessed and used to achieve the expected goals. Human capital can be a form of knowledge, skills, health, social interaction and trust. Jimmy l. Gaol (2014) stated that human capital is the sum of knowledge, skill, experience and other relevant workforce attributes that reside in an organisation's workforce and drive productivity, performance and the achievement of strategic goals

Tudaro (2008:105) stating the significance of human capital is the value of a human being who can be known from the useful working knowledge, professional skills, physical conditions that guarantee the realization of safety, social interaction in development work and confidence in working directly against the influential business performance and job satisfaction.

Maxwell (2009:48) stated that the knowledge, skills, health, social interaction and trust is the human capital which give influence on the improvement of business performance and job satisfaction.

\subsection{The Concept of Performance}

Performance is a level reflection of achievement of the implementation program or policy activities in realizing the goals, objectives, vision and mission of the organization which is poured through the strategic planning of an organization (Moeheriono, 2014:95). According to Gomes (2005:135) Performance is a result of production at a specific job function or activity for a period of time.

Dessler (2000:87) explains that the performance (achievements) is the actual achievements of employees compared to the accomplishments expected of employees. Work achievement of the expected accomplishments are the standards that are arranged as a reference so you can see the performance of employees in accordance with its position compared to the standard are made. Moreover, it can also be seen the performance of the employee against other employees.

Based on some of the definition above, performance can be summed up as the results of the work can be accomplished by a person or a group of people within an organization either quantitatively or qualitatively, in accordance with the powers and duties of the responsibilities of each, in an effort to achieve the objectives of the Organization in question legally, does not violate the law and in accordance with the moral and ethical (Moeheriono, 2014:97).

\subsection{The Concept of Job Satisfaction}

According to Griffin, the satisfaction associated with the employee's attitude towards his work, as well as the situation in cooperation with superiors and fellow co-worker (Setiawan, 2006:188). The opinion suggests that job satisfaction concerns the matter of perception and attitude of a person towards his work. A person may expressed feeling happy or not happy towards her work, or it can indicate an attitude that owned about the work that resulted from their perception.

Dekker (2007:92) States that job satisfaction is assessed based on its high appreciation of the achievement of the above achievements, the need of recognition or appreciation that individual feel satisfied, not in spite of the challenges of the work was entrusted.

Luthans (2005:119) States maintain job satisfaction developed by an organization synonymous with activity option were satisfied on the income received, is satisfied because the interesting 
work, satisfied upon reputation, satisfied over the employment challenge facing, satisfied with their co-workers and are satisfied with the working environment would be created.

\section{Research Methodology}

This research is explanatory research by applying the method of survey. Based on the aspects data of this research is study of analytic because analyzing data from a sample by using the inductive statistics that are generalizable to the population. On the basis of the problem, the research is causality that attempted to explain the causal relationships influence of Human Capital on performance and Satisfaction of medium Entrepreneurs in the city of Kupang.

The source of the data in this study consists of primary and secondary data: 1) primary Data is obtained directly from respondents researchers through the dissemination of questionnaires and interviews. 2 secondary) Data is the diperoeh researchers from a variety of existing document kaitanya with the object of research such as research results or journals, the internet, books and other literature.

The population of the region is a generalization of the object/subject that has certain characteristics and quantity specified by researchers to study and then drawn the conclusion (Sugiyono, 2016:148). The population in this research is the entire Medium entrepreneurs in the city of Kupang. Medium-sized entrepreneur population registered in the Office of Kopersi Micro small and medium enterprises in the city of Kupang until end of December 2016 as much as 280 business units. The sample is part of the number and characteristics of which are owned by the population (Sugiyono,2016:149). The sample in this research is the businessman who moved the medium business sectors in the city of Kupang. As for the determination of the sampling technique used a simple method is to use researchers random sampling that is the taking of a sample of population members performed at random without regard to existing strata in the population (Sugiyono, 2016:152). Furthermore, based on the number of the population determined the number of samples by using the method of withdrawal of samples through approach Yamane (Ferdinan, 2014:174) as follows:

Description:

$$
\mathrm{n}=\frac{N}{1+N d^{2}}
$$

$\mathrm{n}=$ number of Samples

$\mathrm{N}=$ Population Size

$\mathrm{d}=$ the specified Precision or imprecision looseness prosentasi can still be tolerated $(5 \%=0.05)$ or confidence level of $95 \%$.

So for a population of 280 with an error rate of $5 \%$, then the total number of sampelnya is of 165.

Methods of data analysis that is used to describe in this research is descriptive statistics analysis techniques and analysis of Structural Equation Modeling (SEM). The calculation in the descriptive statistical analysis was performed with the help of a computer using the package application program Analysis of Moment Structure (AMOS) 18.0 is one program to process the multidimensional models and tiered and SPSS version 22.0 according to Ferdinand (2014:257). 
A conceptual framework for research needed to describe and design shows influence of exogenous variables are invalid constructs against intervening variables and endogenous variables.

Figure 1. Conceptual Frame

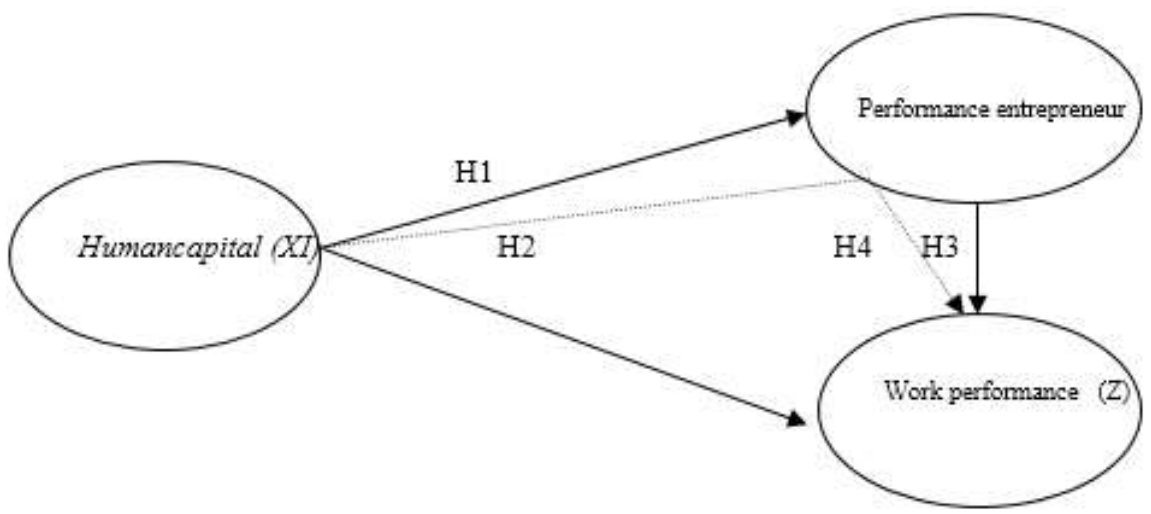

Based on a conceptual framework for research, then researchers may submit a hypothesis as follows: 1) Human capital positive and significant effect on performance Medium entrepreneurs in Kupang; 2) positive and influential Human capital significantly to job satisfaction of secondary employers in Kupang; 3) positive and influential Performance significantly to job satisfaction the medium entrepreneurs in Kupang; 4) Human capital indirectly positive and significant effect against the satisfaction through the performance medium entrepreneurs in the city of Kupang.

\section{Discussion}

Following are the results of the testing of the entire measurement model invalid constructs that will be analyzed in SEM analysis. Based on structural measures eqution model (SEM), obtained a picture of the structure of relationships that make up or explain causality between different factors including:

\section{Human Capital (X 1):}

In this study, Human Capital variables in size with 7 indicators. The following is the specification of the measurement model of Human Capital and its results invalid constructs estimasinya:

Figure 2. Measurement model of constructing human capital-1

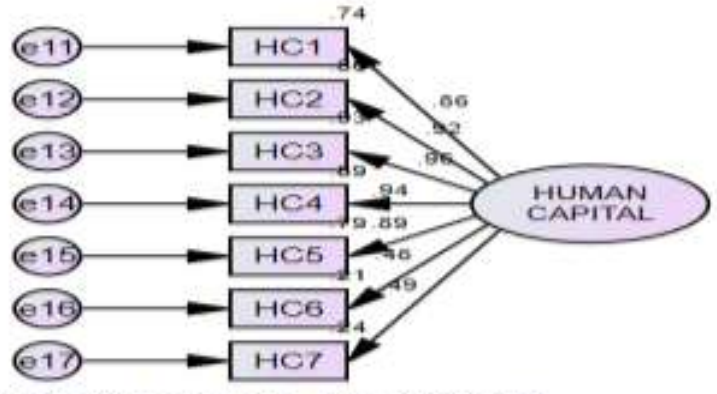

GOODNESS OF FIT MODEL

Prob $=.000:$ Chisquare $=40.355 ; C M I N / D F=2.883$

$\mathrm{RMR}=.040 ; \mathrm{NFI}=.964 ; \mathrm{CFI}=.976$, $\mathrm{TLI}=.964$

$I F I=.976 ; R F I=.946 ; G F I=.931$

$A G F I=.861 ;$ RMSEA $=.107$ 
Based on the results of the estimation of human capital measurement model invalid constructs, then an indicator of emotional capital (HC6) and spiritual capital (Apartamentos) has a loading factor below 0.5 , this indicates that the indicator is not valid in measuring human variables capital (HC) so it should be didrop from the model. The results of the estimation of the model after the emotional indicators capital (HC6) and spiritual capital (Apartamentos) didrop of the model can be seen in Figure 3 below;

Figure 3. Measurement model of constructing human capital-2
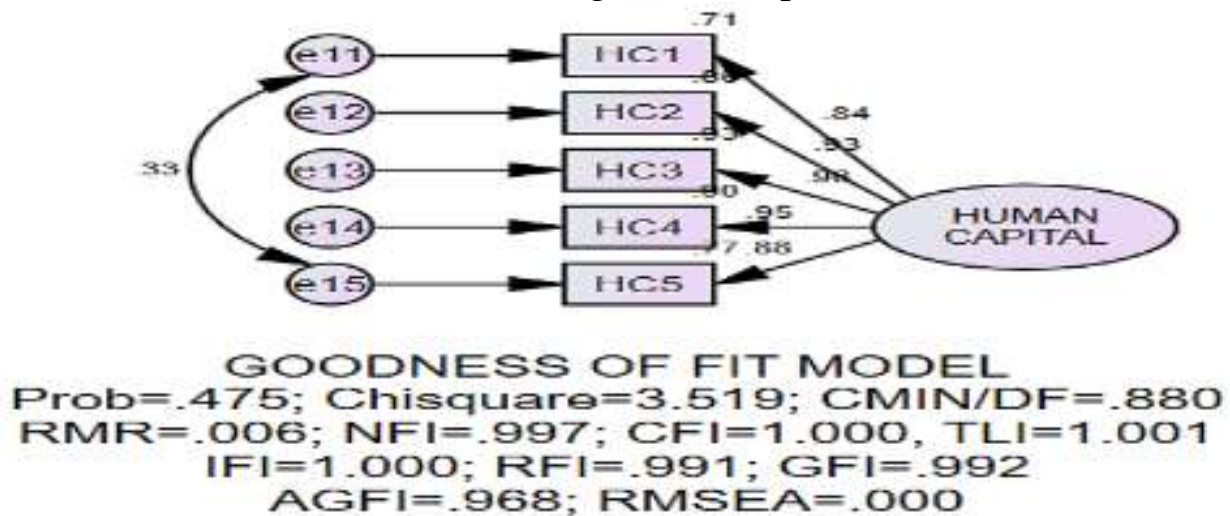

Based on the above picture, after dropping an indicator of emotional capital (H6) and spiritual capital (Apartamentos) as well as some small modifications, all the indicators in the invalid constructs human capital has had a loading factor $>0.5$ and model has had the Goodness of Fit Index (GFI) is a good model, so that the model has decent used to test validity and reliability invalid constructs human capital (X 1).

Table 1. The results of the calculation of the value of CR and AVE invalid constructs Human Capital (X 1)

\begin{tabular}{lllllll}
\hline Variabel & Indikator & $\lambda$ & Validitas & AVE & CR & Reliabilitas \\
\hline \multirow{4}{*}{ Human Capital $(X 1)$} & HC1 & 0,845 & valid & & & \\
\cline { 2 - 4 } & HC2 & 0,924 & valid & & & \\
\cline { 2 - 4 } & HC3 & 0.965 & valid & & & \\
\cline { 2 - 4 } & HC4 & 0.948 & valid & & & \\
\cline { 2 - 4 } & HC5 & 0.881 & valid & & & \\
\hline
\end{tabular}

Source: result of data process 2018

Based on the results of the calculation of the value of the Average Variance Extracdted (AVE) invalid constructs human capital has exceeded the 0.5 and values Critical Ratio (CR) invalid constructs have exceeded the 0.7 . This indicates that all the indicators in the invalid constructs human capital (X 1) have reliability.

Next to know the variable that can be used as indicators of human capital, it can be observed from the regression values and their significance levels $(\mathrm{p})$ where the value of the probability of 0.05 or $0.000<$ as reflections of their respective variables as indicators of human capital as shown in table 2. 
Table 2. Value Regression for Human Capital (X1)

\begin{tabular}{lllll}
\hline Variable Indicator & $\begin{array}{l}\text { Standard } \\
\text { Regression }\end{array}$ & Critical Ratio & Probability $(\boldsymbol{p})$ & Explanation \\
\hline $\mathrm{HC} 1$ & 0.845 & 18,437 & 0,000 & Significant \\
\hline $\mathrm{HC} 2$ & 0.924 & 18,478 & 0,000 & Significant \\
\hline $\mathrm{HC} 3$ & 0.965 & 20,729 & 0,000 & Significant \\
\hline $\mathrm{HC} 4$ & & & & Significant \\
\hline HC5 & 0.948 & 19,668 & 0,000 & Significant
\end{tabular}

Source: processed data 2018

Table 2 shows the data on loading factor based on critical ratio measurement of human capital variables showed the value of positive use for the fifth indicators as seen in table 6 . This means that test results against measurement model of human capital variables from each of these indicators describe a significant $p$ value invalid constructs, so that all the indicators can be included in the next test.

Models of Confirmatory Factor Analysis (CFA) about the relationship between a variable performance indicators employers (Y). In this study, the variable performance of entrepreneurs in size with 5 indicators. The following is the specification of a model performance measurement and the results invalid constructs entrepreneur estimasinya:

Figure 4. Measurement model of constructing performance entrepreneur
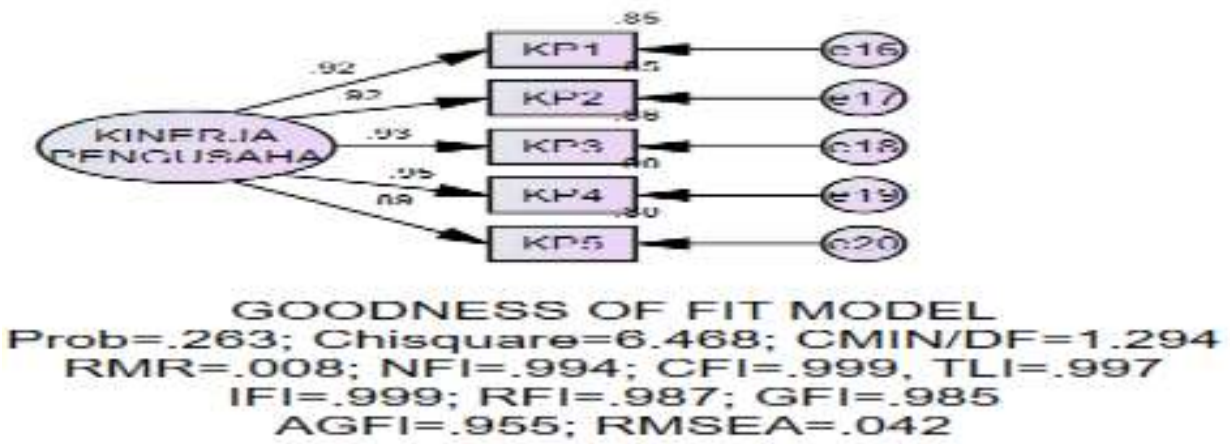

Based on the results estimation model of performance measurement constructs entrepreneurs, throughout the performance indicator in the employers already have invalid constructs loading factor $>0.5$ and model had the goodness of fit of the model is good, so that the model has been used to decent test validity and reliability performance invalid constructs entrepreneurs

Table 3. The results of the calculation of the value of CR and AVE invalid constructs the performance of Employers (Y)

\begin{tabular}{|c|c|c|c|c|c|c|}
\hline Variebel & Indikator & $\lambda$ & Validitas & AVE & CR & Reliabilitas \\
\hline \multirow{2}{*}{ Kinerja Pengusaha } & KP1 & 0,921 & valid & \multirow{2}{*}{0.851} & \multirow{2}{*}{0.955} & \multirow{2}{*}{ reliabel } \\
\hline & KP2 & 0,925 & valid & & & \\
\hline
\end{tabular}




\begin{tabular}{llll}
\hline KP3 & 0,928 & valid \\
\cline { 2 - 4 } KP4 & 0,945 & valid \\
\cline { 2 - 4 } KP5 & 0,894 & valid \\
\hline
\end{tabular}

Source : the result of data process 2018

Based on the results of the calculation of the value of the invalid constructs AVE performance entrepreneurs has exceeded $0.5 \mathrm{CR}$ and value invalid constructs have exceeded the 0.7. This indicates that all the indicators in the invalid constructs a commitment organizations have reliability.

Next to know the variables that can be used as an indicator of the performance of employers, it can be observed from the regression values and their significance levels (p) where the value of the probability of 0.05 or $0.000<$ as reflections of their respective variable in the performance indicators employers as it looked in the table 4:

Table 4. Value Regression for the performance factors of entrepreneurs (Y)

\begin{tabular}{lllll}
\hline Variable Indicator & $\begin{array}{l}\text { Standard } \\
\text { Regression }\end{array}$ & Critical Ratio & Probability $(\boldsymbol{p})$ & explanation \\
\hline KP1 & 0,921 & Fix & 0,000 & Significant \\
\hline KP2 & 0,925 & 21,245 & 0,000 & Significant \\
\hline KP3 & 0,928 & 21,524 & 0,000 & Significant \\
\hline KP4 & 0,945 & 22,726 & 0,000 & Significant \\
\hline KP5 & 0,894 & 19,134 & 0,000 & Significant \\
\hline
\end{tabular}

Source: the result of proces data 2018

The data in table 4 shows the loading factor based on critical performance variables measurement ratio employers showed a positive value for the fifth indicators as seen in table 4 , which meant the test results against measurement model variables pengusaga performance of each of these indicators describe a significant $p$ value invalid constructs, so that all the indicators can be included in the next test.

Models of Confirmatory Factor Analysis (CFA) about the relationship between a variable performance indicators employers (Y). In this study, the variable performance of entrepreneurs in size with 5 indicators. The following is the specification of a model performance measurement and the results of constructs entrepreneur estimation: Figure 5

Figure 5. Measurement model of constructing job satisfaction

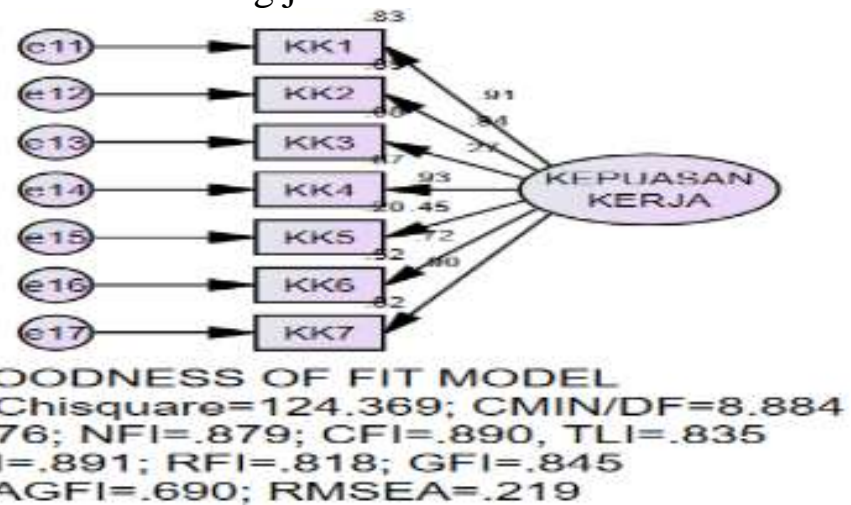


Based on the results of the estimation model of measurement, indicators of job satisfaction invalid constructs reputation (KK3), control (KK5) and co-workers (KK6) has a loading factor below 0.5 , this indicates that the indicator is not valid in measuring variables job satisfaction so that should be at the drop of a model. The results of the estimation of the model after the reputation indicator (KK3), control (KK5) and co-workers (KK6) at the drop of a model can be seen in the following image:

Figure 6. Measurement model of constructing job satisfaction

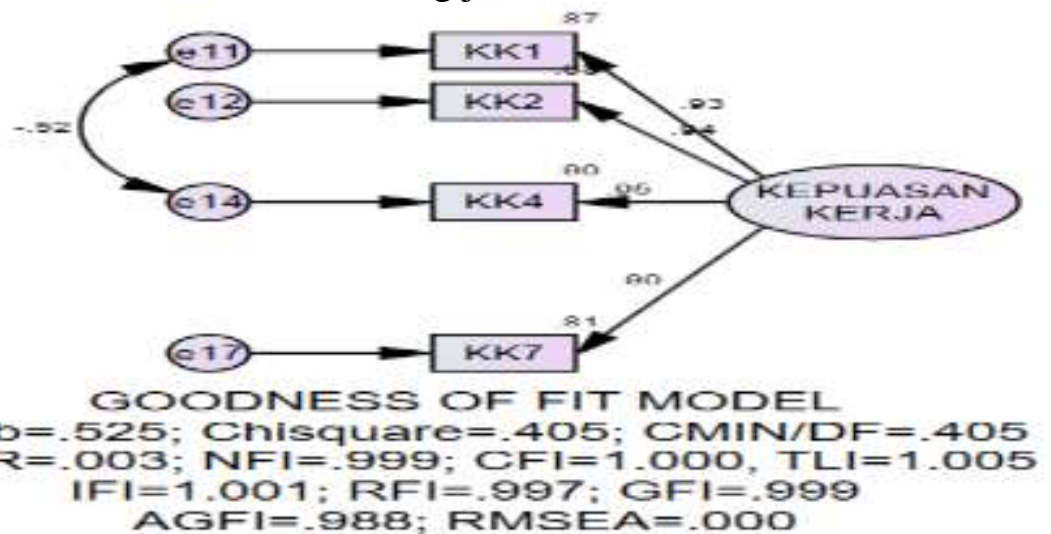

Based on the above picture, after dropping the reputation indicator (KK3), control (KK5) and co-workers (KK6) as well as some small modifications, all the indicators in the invalid constructs job satisfaction has had a loading factor $>0.5$ and model has had goodness of fit of the model is good, so that the model has decent used to test validity and reliability invalid constructs job satisfaction.

Table 5. The results of value calculation of CR and AVE job satisfaction (Z)

\begin{tabular}{lllllll}
\hline Variebel & Indikator & $\boldsymbol{\lambda}$ & Validitas & AVE & CR & Reliabilitas \\
\hline \multirow{2}{*}{ Kepuasan Kerja } & KK1 & 0.929 & valid & & \\
\cline { 2 - 4 } & KK2 & 0.939 & valid & & \\
\cline { 2 - 4 } & KK4 & 0.944 & valid & & reliabel \\
\cline { 2 - 4 } & KK7 & 0.902 & valid & & \\
\hline
\end{tabular}

Source : the result of data process 2018

Based on the results of value calculation of the constructs AVE job satisfaction has exceeded the 0.5 and values $C R$ invalid constructs have exceeded the 0.7 . This indicates that all the indicators in the invalid constructs job satisfaction had been your reliable supporter.

Next to know the variables that can be used as indicators of job satisfaction, then it can be observed from the regression values and their significance levels $(p)$ where the value of the probability of 0.05 or $0.000<$ as reflections of their respective variables in the indicators of job satisfaction as shown in table 10 below: 
Table 6. Value Regression to factor in job satisfaction $(\mathrm{Z})$

\begin{tabular}{lllll}
\hline $\begin{array}{l}\text { Variable } \\
\text { Indicator }\end{array}$ & $\begin{array}{l}\text { Standard } \\
\text { Regression }\end{array}$ & $\begin{array}{l}\text { Critical } \\
\text { Ratio }\end{array}$ & $\begin{array}{l}\text { Probability } \\
(\boldsymbol{p})\end{array}$ & explanation \\
\hline KK1 & 0.929 & Fix & 0,000 & Significant \\
\hline KK2 & 0.939 & 22.441 & 0,000 & Significant \\
\hline KK4 & 0.944 & 19.400 & 0,000 & Significant \\
\hline KK7 & 0.902 & 19.731 & 0,000 & Significant
\end{tabular}

Sumber : result of prosesing data 2018

The data in table 10 shows the loading factor based on the critical measurement of job satisfaction variable ratio showed a positive value for the four indicators. This means that test results against measurement model of job satisfaction variables from each of these indicators describe a significant $p$ value invalid constructs, so that all the indicators can be included in the next test

The results of hypothesis testing as contained in table 7 below, then it is seen that the whole model line gives a positive and significant influence.

Table 7. Hypothesis testing Matrix Direct effects, Indirect Effect and Total Effect

\begin{tabular}{|c|c|c|c|c|c|c|c|c|}
\hline \multirow[t]{2}{*}{ No } & \multirow{2}{*}{$\begin{array}{l}\text { Variable } \\
\text { Ecsogen }\end{array}$} & \multirow{2}{*}{$\begin{array}{l}\text { Variable } \\
\text { Intervening }\end{array}$} & \multirow{2}{*}{$\begin{array}{l}\text { Variable } \\
\text { Endogen }\end{array}$} & \multicolumn{5}{|c|}{ Standardized } \\
\hline & & & & $\begin{array}{l}\text { Direct } \\
\text { Effect }\end{array}$ & $\begin{array}{l}\text { Indirect } \\
\text { Effect }\end{array}$ & $\begin{array}{l}\text { Total } \\
\text { Effect }\end{array}$ & $\begin{array}{l}P \text { - } \\
\text { Value }\end{array}$ & explanation \\
\hline \multirow[t]{2}{*}{1} & $\begin{array}{l}\text { Human } \\
\text { Capital (X1) }\end{array}$ & $\begin{array}{l}\text { Performance } \\
\text { entrepreneur }(\mathrm{Y})\end{array}$ & & 0,301 & & 0,301 & 0,000 & \\
\hline & & & - & & - & & & Significant \\
\hline \multirow[t]{2}{*}{2} & $\begin{array}{l}\text { Human } \\
\text { Capital (X1) }\end{array}$ & & $\begin{array}{ll}\text { Job } & \text { satisfaction } \\
\text { (Z) } & \\
\end{array}$ & 0,138 & - & 0,138 & 0,030 & \\
\hline & & - & & & & & & Significant \\
\hline \multirow[t]{2}{*}{3} & & $\begin{array}{l}\text { Performance } \\
\text { entrepreneur }(\mathrm{Y})\end{array}$ & $\begin{array}{ll}\text { Job } & \text { satisfaction } \\
(\mathrm{Z}) & \end{array}$ & 0,494 & - & 0,494 & 0,000 & \\
\hline & - & & & & & & & Significant \\
\hline \multirow[t]{2}{*}{4} & $\begin{array}{l}\text { Human } \\
\text { Capital (X1) }\end{array}$ & $\begin{array}{l}\text { Performance } \\
\text { entrepreneur }(\mathrm{Y})\end{array}$ & $\begin{array}{ll}\text { Job } & \text { satisfaction } \\
(\mathrm{Z}) & \end{array}$ & - & 0,148 & 0,148 & - & $(+)$ \\
\hline & & & & & & & & Significant \\
\hline
\end{tabular}

Source; the result of process data 2018

Research findings that is as follows:

1. Human capital has a positive and significant influence on performance medium entrepreneurs with the value of the $\mathrm{p}$ value obtained $=0.000(<0.05)$ and the value of the direct influence of 0.301 .

2. Human capital is positive and significant effect against the medium entrepreneurs job satisfaction with the value of the p value obtained $=0.030(<0.05)$ and the value of the direct influence of 0.138 .

3. Performance of a positive and significant effect against the medium entrepreneurs job satisfaction with the value of the $p$ value obtained $=0.000(<0.05)$ and the value of the direct influence of 0.494 . 
4. Human capital is positive and significant effect against the satisfaction of entrepreneurs through the performance medium entrepreneurs with the value of the $\mathrm{p}$ value obtained $=0.030(<0.05)$ and the value of indirect influence of 0.148 .

5. Capital is positive and significant effect against the satisfaction of entrepreneurs through the performance medium entrepreneurs with the value of the $\mathrm{p}$ value obtained $=0.030(<0.05)$ and the value of indirect influence of 0.148 .

6. Conclusions based on analysis of the results of research and discussion, can be summed up as follows:

a. Human capital (X) is positive and significant effect on performance medium entrepreneurs (Y).

b. Human capital $(\mathrm{X})$ is positive and significant effect against the satisfaction of entrepreneurs $(\mathrm{Z})$.

c. Performance of entrepreneurs (Y) a positive and significant effect against the satisfaction of entrepreneurs $(\mathrm{Z})$.

d. Human capital $(\mathrm{X})$ is positive and significant effect against the satisfaction of entrepreneurs $(\mathrm{Z})$ through the performance medium entrepreneurs $(\mathrm{Y})$.

\section{Conclusions}

Human capital $(\mathrm{X})$ is positive and significant effect on performance medium entrepreneurs (Y). Human capital (X) is positive and significant effect against the satisfaction of entrepreneurs (Z). Performance of entrepreneurs (Y) a positive and significant effect against the satisfaction of entrepreneurs $(\mathrm{Z})$. Human capital $(\mathrm{X})$ is positive and significant effect against the satisfaction of entrepreneurs $(Z)$ through the performance medium entrepreneurs (Y).

\section{References}

Becker, Hatt, 2009, The Human Resourcein Management, New York, John Wiley and Son Inc. Dessler, 2000, Motivasi dan Perilaku Organisasi, Penerbit PT Arga, Jakarta.

Dekker, Harold, 2007. Essentials of Management. Fifth Edition, McGraw Hill, Inc., Singapore. 2010. Management: Task, Responsibilities, Practice, Harper \& Row, New York.

Ferdinand, Augusty, 2006. Structural Equation Modeling dalam Penelitian Manajemen. FE Universitas Diponegoro, Semarang.

-----------, 2014, Metode Penelitian Manajemen, Badan Penerbit Universitas Diponegoro,Semarang.

Furtwengler, Dale, 2010. Performance. Published by Harper T \& Row, New York.

Gibson, James L, 2007. Organizational Behavior, Structure, Process. 3, edt., Dallas, Business Publications, Inc.

Gaol L. Jimmy, 2014, A to Z Human Capital, Penerbit PT Gramedia Widiasarana Indonesia, Jakarta.

---------, 2003, Behavior in Organization, $8^{\text {th }}$ edition, Pearson Education, Inc, New Jersey.

Gomes, Faulkes, 2003. Management of Personal Satisfied In Prospective Theories. http://www.journalmotivation.com.id.

-------------, 2003, Manajemen Personalia \& Sumber Daya Manusia, Edisi Revisi, Penerbit BPFE, Yogyakarta. 
Luthans,Fred, 2005. Organizational Behavior. New York, McGraw-Hill Book Company, 3rd, edt.

2005. Essentials of Organizational Behavior: Management Research. Prentice Hall International lnc, New Jersey.

Moeheriono, 2014, Pengukuran Kinerja Berbasis Kopetensi. Edisi Revisi, Penerbit Rajawali Pers, Jakarta.

Maswell, Morgan, 2009. Organization Theory, A Macro Perspective for management, Prentice-Hall, New York.

Robbins, P. Stephen, P., 2010. Organizational Behavior. Prentice Hall Cliffs, New Jersey. Sugiyono,2016. Metode Penelitian Manajemen, Cetakan ke 5, Penerbit Alfabeta, Bandung. Tudaro, GR., 2005. Human Resource Management. Published by McGraw Hill, USA. 2008. Managing Performance Appraisal System. StrathclydeBusiness School, UK.

Wibowo, 2008, Manajemen Perubahan, Edisi Kedua, Jakarta, PT Raja Grafindo Persada. ., 2012, Manajemen Kinerja. Edisi Ketiga, Jakarta , PT. Raya Gratindo Persada. 